Original article

\title{
Pengaruh pemberian ekstrak daun kelor (Moringa oleifera Lam.) terhadap motilitas dan viabilitas spermatozoa tikus (Rattus norvegicus) dengan paparan panas
}

\section{The effect of Moringa (Moringa oleifera Lam.) leaf extract on the motility and viability of spermatozoa of heat exposed rats (Rattus norvegicus)}

\author{
Noor Ayu Arinda Octaviani ${ }^{1}$, Budi Utomo ${ }^{2 *} \mathbb{D}$, Agus Sunarso ${ }^{3}$, Iwan Sahrial Hamid ${ }^{4}$, \\ Sri Pantja Madyawati² ${ }^{\circledR}$, Tri Wahyu Suprayogi ${ }^{2} \odot$ \\ ${ }^{1}$ Faculty of Veterinary Medicine, ${ }^{2}$ Division of Veterinary Reproduction, \\ ${ }^{3}$ Division of Veterinary Parasitology, ${ }^{4}$ Division of Veterinary Basic Medicine, \\ Faculty of Veterinary Medicine Universitas Airlangga \\ *Corresponding author, e-mail: budi_reprovet@yahoo.com
}

Open access under CC BY - SA license, DOI: 10.20473/ovz.v10i3.2021.65-71

Received July 13 2021, Revised August 29 2021, Accepted November 212021

Published online December 12021

\begin{abstract}
This study aimed to determine the effect of Moringa (Moringa oleifera Lam.) leaf extract on the viability and motility of spermatozoa of rats (Rattus norvegicus) exposed to heat $\left(40^{\circ} \mathrm{C}\right)$. A total of 25 rats aged 2.5 months and weighed 200 grams were randomly divided into five groups. Rats in $\mathrm{K}(-)$ group were not exposed to heat and without Moringa leaf extract administration. Rats in $\mathrm{K}(+)$ group were exposed to heat $\left(40{ }^{\circ} \mathrm{C}\right)$ for 1 hour daily without Moringa leaf extract administration. Meanwhile, rats in P1, P2, and P3 groups were administrated with Moringa leaf extract 100, 200, and $400 \mathrm{mg} / \mathrm{kg} \mathrm{BW} /$ day, then exposed to $40^{\circ} \mathrm{C} 1$ hour daily for 14 days. The results showed that exposure to $40{ }^{\circ} \mathrm{C}$ one hour per day for 14 days in $\mathrm{K}(+)$ group caused a decrease $(\mathrm{p}<0.05)$ on viability and motility of rat spermatozoa compared to those of the $\mathrm{K}(-)$ group. The administration of Moringa leaf extract (P1, P2, and P3 groups) was followed by an increase $(\mathrm{p}<0.05)$ in viability and motility of rat spermatozoa compared to the $\mathrm{K}(+)$ group. Viability and motility of rat spermatozoa in the P3 group (given Moringa leaf extract $400 \mathrm{mg} / \mathrm{kg}$ BW/day and exposed to $40{ }^{\circ} \mathrm{C} 1$ hour daily for 14 days) were not significantly different ( $\mathrm{p}>0.05$ ) compared to the viability and motility of rat spermatozoa in $\mathrm{K}(-)$ group. It could be concluded that administration of Moringa leaf extract $400 \mathrm{mg} / \mathrm{kg}$ BW/day can maintain the viability and motility of spermatozoa in white rats exposed to heat.
\end{abstract}

Keywords: heat, Moringa oleifera, motility, spermatozoa, viability

\section{PENDAHULUAN}

Pemanasan global merupakan proses terjadinya peningkatan suhu rata-rata permukaanbumi oleh peningkatan konsentrasi gas yang menghalangi pantulan energi sinar matahari dari bumi yang menyebabkan peningkatan efek rumah kaca sehingga bumi menjadi lebih panas (Subianto et al., 2018; Pratama, 2019). Peningkatan jumlah polusi kendaraan, berkurangnya lahan hutan, bertambahnya sumber panas buatan yang berasal dari kegiatan industri dan bangunan merupakan penyebab suhu udara semakin panas (Andani et al., 2018).

Suhu berperan penting dalam perkembangan 
sel germinal serta siklus reproduksi makhluk hidup. Suhu optimal testis dipertahankan pada 2 ${ }^{\circ} \mathrm{C}$ (manusia) atau $8{ }^{\circ} \mathrm{C}$ (tikus) di bawah suhu tubuh. Hal ini dicapai dengan pengaturan aliran darah melalui posisi mendekat atau menjauhi panas tubuh oleh otot kremaster dan otot polos dartos di skrotum (Silva et al., 2018; Sarfraz et al., 2019). Paparan panas dapat berakibat kegagalan termoregulasi skrotum, meningkatkan suhu testis, yang dapat menyebabkan stres panas genital yang merugikan spermatogenesis (Tavalaee et al., 2018).

Suhu udara yang panas berdampak negatif terhadap tubuh dengan menyebabkan stress oksidatif yang mampu menurunkan kualitas spermatozoa (Ermiza, 2012). Antioksidan dapat mencegah reaksi rantai peroksidasi yang disebabkan oleh stress oksidatif (Lamando et $a l .$, 2014). Flavonoid memiliki potensi yang besar untuk mencegah terjadinya stres oksidatif akibat tingginya reactive oxygen species (ROS) (Arifin dan Ibrahim, 2018; Agati et al., 2020). Salah satu tanaman yang mengandung flavonoid adalah tanaman kelor (Moringa oleifera Lam.) yang mengandung antioksidan tinggi (Das et al., 2012). Sejauh ini belum dijumpai publikasi tentang pengaruh ekstrak daun kelor terhadap viabilitas dan motilitas spermatozoa tikus yang terpapar panas.

Berdasarkan uraian di atas, dilakukan penelitian untuk mengetahui pengaruh pemberian ekstrak daun kelor (Moringa oleifera Lam) terhadap motilitas dan viabilitas spermatozoa tikus putih (Rattus norvegicus) dengan paparan panas.

\section{MATERI DAN METODE}

\section{Persetujuan komisi etik}

Penelitian ini menggunakan tikus putih (Rattus norvegicus) strain Wistar jantan berumur 10 minggu dengan berat badan ratarata 200 gram sebanyak 25 ekor. Prosedur penelitian telah ini disetujui oleh Komisi Etik Penelitian Penggunaan Hewan Coba (Animal Care and Use Committee) Fakultas Kedokteran Hewan Universitas Airlangga No. 1.KE.137.07.2019.

\section{Ekstraksi daun kelor}

Daun kelor dicuci bersih, dikeringkan pada suhu kamar, kemudian ditumbuk dan disaring dengan ayakan 40 Mesh. Satu kilo gram serbuk daun kelor dimasukkan ke dalam labu Erlenmeyer dan direndam dalam etanol $96 \%$ untuk maserasi, selama 3 hari dan diaduk setiap hari. Maserat dikeringkan dalam rotary evaporator (Rotavapor Buchi RE301 Malaysia) pada $50 \mathrm{rpm}, 40{ }^{\circ} \mathrm{C}$, dan disuspensikan kembali dalam natrium Karboksimetil selulosa (CMCNa) $1 \%$ sebagai larutan ekstrak daun kelor (EDK) untuk perlakuan pada hewan coba (Das et al., 2012).

\section{Perlakuan hewan coba}

Tikus putih (Rattus norvegicus) sebanyak 25 ekor yang dibagi secara acak menjadi lima kelompok perlakuan. Adaptasi pemeliharaan di kandang hewan coba dilakukan selama tujuh hari, perlakuan dimulai pada hari ke-8. Tikus putih kelompok K (-) diberi larutan CMC-Na, dan tidak diberi paparan panas. Tikus putih kelompok $\mathrm{K}(+)$ diberi larutan CMC-Na $1 \%$, dan diberi paparan panas. Tikus putih kelompok P1, P2 dan P3 diberi EDK dengan dosis 100, 200 dan $400 \mathrm{mg} / \mathrm{kg}$ BB/hari dan satu jam kemudian dipapar dengan panas suhu $40{ }^{\circ} \mathrm{C}$. Pemberian larutan CMC-Na $1 \%$ dan larutan EDK dilakukan secara per oral sebanyak $1 \mathrm{ml}$ menggunakan sonde lambung, di pagi hari sebelum makan. Pemaparan panas dilakukan pada bilik berukuran 50 x 30 x 40 $\mathrm{cm}$ dengan lampu pemanas dan termostat untuk menjaga suhu tetap stabil $40{ }^{\circ} \mathrm{C}$ (Rohmah et al., 2018).

Selama penelitian, tikus diberi makan dan minum secara ad libitum. Perlakuan dilakukan selama 14 hari dan pada hari ke-22 pemeliharaan, semua tikus dikorbankan dengan cara dieutanasia dengan ketamine dan xylazin kemudian dilakukan pembedahan skrotum untuk mengambil cauda epididymis. Pada posisi $1 \mathrm{~cm}$ di bawah korda spermatika diklem, kemudian dipotong dan dikeluarkan spermatozoa dengan penekanan dan pendorongan pada bagian cauda epididymis, ditampung pada cawan petri berukuran $3,5 \mathrm{~cm}$ (Nunc $^{\mathrm{TM}}$, Thermo Scientific) yang berisi 1 $\mathrm{ml} \mathrm{NaCL} 0,9 \%$ dan diaduk agar menjadi homogen (Rohmah et al., 2018). 


\section{Pemeriksaan viabilitas spermatozoa}

Satu tetes campuran spermatozoa/ $\mathrm{NaCl}$ $0,9 \%$ diletakkan pada gelas obyek lalu dicampur dengan satu tetes zat warna eosin nigrosin, dihomogenkan, dibuat preparat ulas, kemudian difiksasi diatas nyala api. Pengamatan dilakukan dengan mikroskop cahaya (Nikon Eclipse E100) perbesaran 400 kali. Sel spermatozoa yang hidup tidak terwarnai, sedangkan spermatozoa yang mati berwarna merah keunguan. Penghitungan viabilitas spermatozoa (persentase spermatozoa hidup) didapat dari pemeriksaan 1000 spermatozoa (Handayani et al., 2021).

\section{Pemeriksaan motilitas spermatozoa}

Satu tetes larutan $\mathrm{NaCl} 0,9 \%$ dan satu tetes campuran spermatozoa/ $\mathrm{NaCl} \quad 0,9 \%$ diletakkan pada gelas obyek, dicampur sampai homogen lalu ditutup dengan kaca penutup dan diperiksa di bawah mikroskop cahaya (Nikon Eclipse E100) dengan perbesaran 400 kali. Pemeriksaan motilitas spermatozoa dilakukan pada suhu kamar agar spermatozoa mempunyai pergerakan yang optimal (Handayani et al., 2021). Penilaian dilakukan berdasarkan perhitungan persentase gerakan individu spermatozoa maju ke depan (progresif) dari pemeriksaan 1000 spermatozoa (Widiantoro et al., 2021).

\section{Analisis statistik}

Data viabilitas dan motilitas spermatozoa dianalisis menggunakan one way Anova dilanjutkan dengan uji Jarak Berganda Duncan sebagai perbandingan antar kelompok. Uji statistik dilakukan pada taraf kepercayaan 95\% menggunakan Statistical Product and Service Solutions (SPSS version 23; IBM Corp., Armonk, NY, USA).

\section{HASIL}

Hasil penelitian menunjukkan bahwa paparan suhu $40{ }^{\circ} \mathrm{C} 1$ jam per hari selama 14 hari pada kelompok $\mathrm{K}(+)$ menyebabkan penurunan $(\mathrm{p}<0,05)$ viabilitas dan motilitas spermatozoa tikus dibandingkan kelompok $\mathrm{K}$ (-). Pemberian EDK (kelompok P1, P2, dan P3) diikuti dengan kenaikan ( $p<0,05)$ viabilitas dan motilitas spermatozoa tikus dibandingkan kelompok K (+). Viabilitas dan motilitas spermatozoa tikus kelompok P3 (diberi EDK $400 \mathrm{mg} / \mathrm{kg} \mathrm{BB} /$ hari dan dipapar panas $40{ }^{\circ} \mathrm{C} 1 \mathrm{jam} /$ hari selama 14 hari) tidak berbeda nyata $(\mathrm{p}>0,05)$ dibandingkan dengan viabilitas dan motilitas spermatozoa tikus kelompok K (-) (Tabel 1).

Tabel 1 Viabilitas dan motilitas spermatozoa tikus putih (Rattus norvegicus) yang diberi ekstrak daun kelor (Moringa oleifera Lam.) dan dipapar panas

\begin{tabular}{ccc}
\hline & viabilitas & motilitas \\
\hline K (-) & $78,01 \pm 8,09^{\mathrm{c}}$ & $66,00 \pm 6,51^{\mathrm{c}}$ \\
$\mathrm{K}(+)$ & $29,94 \pm 4,64^{\mathrm{a}}$ & $18,00 \pm 2,73^{\mathrm{a}}$ \\
P1 & $45,45 \pm 9,50^{\mathrm{b}}$ & $36,00 \pm 6,51^{\mathrm{b}}$ \\
P2 & $52,32 \pm 8,12^{\mathrm{b}}$ & $43,00 \pm 5,70^{\mathrm{b}}$ \\
P3 & $69,51 \pm 12,98^{\mathrm{bc}}$ & $57,00 \pm 7,58^{\mathrm{c}}$ \\
\hline
\end{tabular}

Superskrip yang berbeda menunjukan perbedaan nyata $(\mathrm{p}<0,05)$; $\mathrm{K}(-)$ : tikus putih (Rattus norvegicus) tidak dipapar panas dan tanpa diberi ekstrak daun kelor; $\mathrm{K}(+)$ : tikus putih (Rattus norvegicus) tanpa diberi ekstrak daun kelor dan dipapar panas $40^{\circ} \mathrm{C}$ selama 1 jam/hari ; P1, P2, dan P3: tikus putih (Rattus norvegicus) diberi ekstrak daun kelor 100, 200, dan $400 \mathrm{mg} / \mathrm{kg} \mathrm{BB} /$ hari per oral diikuti paparan panas $40^{\circ} \mathrm{C} 1$ jam/hari selama 14 hari; ulangan $=5$.

\section{DISKUSI}

Spermatogenesis adalah serangkaian proses kompleks yang meliputi perubahan dari spermatogonia menjadi spermatozoa matang. Proses spermatogenesis dipengaruhi oleh berbagai faktor, termasuk stres panas yang mengurangi kualitas spermatozoa dan berdampak negatif pada kesuburan. Pengaruh paparan panas pada siklus spermatogenesis melibatkan proses apoptosis, kerusakan DNA dan autophagy (Tavalaee et al., 2018). Panas sebagai bentuk stres fisik juga mengaktifkan neuroendokrin sumbu Hipotalamus-HipofisaTestis (HHT), menyebabkan pengeluaran neurohormon Corticotropin Releasing Hormone (CRH). Peningkatan CRH menimbulkan penurunan Gonadotropin Releasing Hormone (GnRH) menyebabkan penurunan produksi 
Follicle Stimulating Hormon (FSH) dan Luteinizing Hormone (LH) oleh adenohipofisis. Terjadinya gangguan pada sumbu HHT, berupa penurunan LH, FSH dan testosteron selanjutnya mengganggu kualitas spermatozoa. Paparan panas juga mengakibatkan gangguan fungsi epididimis dalam pematangan spermatozoa melalui reaksi enzimatis untuk memberikan pasokan bahan makanan terutama glukosa sebagai substrat metabolisme spermatozoa. Aktivitas maksimum sebagian besar enzim berlangsung sekitar suhu $37^{\circ} \mathrm{C}$. Pada suhu yang lebih tinggi terjadi denaturasi berupa hilangnya struktur skunder dan tersier, sehingga enzim mengalami gangguan fungsi (de La Salles et al., 2017).

Perlakuan penelitian ini berlangsung selama 14 hari. Siklus spermatogenesis pada tikus putih adalah 12 hari, yang meliputi tahapan pembentukan spermatogonium, spermatosit primer, spermatosit sekunder, spermatid awal, dan spermatid akhir (Solihati et al., 2013). Hasil penelitian ini menunjukkan bahwa paparan suhu $40{ }^{\circ} \mathrm{C}$ satu jam per hari selama 14 hari menyebabkan penurunan viabilitas dan motilitas spermatozoa dibandingkan pada tikus normal (Tabel 1). Penelitian sebelumnya menunjukkan bahwa terjadi penurunan jumlah sel Leydig, sel Sertoli, dan sel spermatogenik tikus yang terpapar panas (Panggalih et al., 2021). Demikian juga terjadi penurunan jumlah sel Leydig, diameter tubulus seminiferus, dan berat testis pada mencit (Mus musculus) yang terpapar panas (Prastyaningtyas et al., 2021). Paparan suhu 40-42 ${ }^{\circ} \mathrm{C} 45$ menit per hari selama 36 hari menurunkan motilitas spermatozoa mencit (Ermiza, 2012).

Paparan panas secara terus menerus dapat menyebabkan stres oksidatif, sehingga kadar ROS lebih tinggi dibandingkan antioksidan endogen (Sabés-Alsina et al., 2016). Stress oksidatif didefinisikan sebagai kerusakan yang disebabkan ketidakseimbangan antara ROS dengan antioksidan (El-Tantawy, 2016). Sifat ROS sangat reaktif karena terdapat sebuah elektron terluar yang tidak memiliki pasangan sehingga mudah mengambil elektron molekul lain sehingga mengakibatkan kerusakan sel (Bardaweel et al., 2018). Molekul-molekul yang dapat menjadi target reaksi ROS adalah lemak, protein dan DNA pada spermatozoa (Durairajanayagam et al., 2014). Molekul ROS pertama mempengaruhi asam lemak tak jenuh ganda pada membran plasma spermatozoa, ditandai dengan pembentukan peroksidasi lipid, yang mengganggu membran plasma spermatozoa (Riesco et al., 2021). Peningkatan permeabilitas membran diikuti hilangnya kemampuan untuk mengatur konsentrasi ion Kalsium intraseluler yang berfungsi mengontrol pergerakan spermatozoa (Durairajanayagam et al., 2015). Kerusakan membran plasama spermatozoa juga mengakibatkan kerusakan struktur DNA sehingga berdampak negatif pada viabilitas spermatozoa (Alahmar, 2019). Paparan panas menimbulkan gangguan terhadap fungsi sel dan kerusakan sel, seperti apoptosis. Molekul DNA sangat peka terhadap ROS karena langsung merusak purin dan pirimidin yang dapat memutuskan rantai DNA dan selanjutnya menyebabkan kematian spermatozoa (Wagner et al., 2017). Molekul ROS juga merusak membran plasma dengan menggangu proses pompa $\mathrm{Na}+\mathrm{K}+$ dan proses homeostasis Ca2+ (Margaritelis et al., 2016). Permeabilitas membran juga erat kaitannya dengan transportasi nutrisi yang penting peranananya dalam metabolisme sel. Terganggunya permeabilitas membran spermatozoa menyebabkan terganggunya pasokan nutrisi yang selanjutnya berakibat kematian spermatozoa (Wagner et al., 2017). Keadaan membran yang rusak menyebabkan metabolisme sel terganggu dan permeabilitas membran menjadi sangat tinggi sehingga zat warna eosin nigrosin dapat masuk melewati membran ditandai dengan kepala spermatozoa berwarna merah (Prastyaningtyas et al., 2021).

Pemberian EDK menyebabkan kenaikan persentase viabilitas dan motilitas spermatozoa tikus dibandingkan dengan kelompok tikus yang hanya dipapar panas. Viabilitas dan motilitas spermatozoa tikus yang diberi asupan EDK $400 \mathrm{mg} / \mathrm{kg} \mathrm{BB} / \mathrm{hari}$ dan dipapar panas $40{ }^{\circ} \mathrm{C} 1 \mathrm{jam} / \mathrm{hari}$ selama 14 hari) sama dengan pada tikus tanpa paparan panas dan tanpa pemberian EDK. Hal ini diduga disebabkan oleh antioksidan senyawa flavonoid yang terkandung dalam EDK (Das et al., 2012; Agati et al., 2020). Mekanisme 
kerja antioksidan adalah mendonorkan sebagian elektron kepada sel atau molekul yang rusak sehingga kembali pada kondisi normal. Antioksidan alami mempunyai efek sitotoksik dan residu yang rendah dalam tubuh (Raharjo et al., 2017). Fenol merupakan salah satu antioksidan alami. Total fenol yang dikonsumsi menunjukkan tingginya aktivitas antioksidan (Badriyah et al., 2017). Senyawa fenol alami yang telah diketahui adalah flavonoid yang merupakan senyawa yang disajikan secara luas di alam (Utami et al., 2020). Kandungan total fenol pada daun kelor lebih tinggi dibanding dengan daun bayam merah (Novita et al., 2016). Asupan daun kelor pada pakan tikus terbukti dapat meningkatkan viabilitas dan motilitas spermatozoa (Ogunsola et al., 2017).

Pemberian antioksidan berupa flavonoid dapat melindungi membran plasma dari ROS sehingga integritas membran masih dalam keadaan utuh (Agati et al., 2013), dan metabolisme pembentukan ATP dapat berlangsung dengan baik (de los Reyes et al., 2011; Estrada et al., 2017). Molekul ATP merupakan sumber energi bagi motilitas spermatozoa (Vadnais et al., 2014; Wagner, 2017). Antioksidan mampu menghambat dan menurunkan aktivitas stres oksidatif yang disebabkan oleh ROS yang berlebihan dalam tubuh (Pratiwi et al., 2021). Flavonoid diketahui dapat menurunkan aktivitas ROS (Pizzino et al., 2017) dengan cara menyumbangkan elektron dapat menangkal rantai peroksidasi dan dapat mempertahankan membran plasma (Cahyadi et al., 2016) sehingga meningkatan persentase hidup dan motilitas spermatozoa pada tikus yang terpapar panas.

\section{KESIMPULAN}

Pemberian ekstrak daun kelor (Moringa oleifera Lam.) $400 \mathrm{mg} / \mathrm{kg} \mathrm{BB} /$ hari dapat mempertahankan motilitas dan viabilitas spermatozoa tikus putih yang terpapar panas.

\section{DAFTAR PUSTAKA}

Agati G, Brunetti C, Di Ferdinando M, Ferrini F, Pollastri S, Tattini M. 2013. Functional roles of flavonoids in photoprotection: new evidence, lessons from the past. Plant Physiol Biochem. 72: 35-45.

Agati G, Brunetti C, Fini A, Gori A, Guidi L, Landi M, Sebastiani F, Tattini M. 2020. Are Flavonoids Effective Antioxidants in Plants? Twenty Years of Our Investigation. Antioxidants (Basel) 9: 1098.

Alahmar AT. 2019. Role of Oxidative Stress in Male Infertility: An Updated Review. J Hum Reprod Sci. 12: 4-18.

Andani ND, Sasmito B, Hani'ah H. 2018. Pengaruh Perubahan Tutupan Lahan Terhadap Fenomena Urban Heat Island dan Keterkaitannya dengan tingkat Kenyamanan Termal (Temperature Humidity Index) di Kota semarang. J Geodesi Undip. 7: 53-65.

Arifin B, Ibrahim S. 2018. Struktur, Bioaktivitas dan Antioksidan Flavonoid. J Zarah. 6: 21-9.

Badriyah B, Achmadi J, Nuswantara LK. 2017. Kelarutan Senyawa Fenolik dan Aktivitas Antioksidan Daun Kelor (Moringa Olifera Lam) di dalam Rumen Secara In Vitro. J Peternakan Indonesia. 19: 116-21.

Bardaweel SK, Gul M, Alzweiri M, Ishaqat A, ALSalamat HA, Bashatwah RM. 2018. Reactive Oxygen Species: the Dual Role in Physiological and Pathological Conditions of the Human Body. Eurasian $\mathrm{J}$ Med. 50:193-201.

Cahyadi TRT, Christiyanto M, Setiatin ET. 2016. Persentase hidup dan abnormalitas sel spermatozoa kambing Peranakan Etawah (PE) dengan pakan yang disuplementasi Daun Binahong (Anredera cordifolia (Ten.) Steenis). Anim Agric J. 5: 23-32.

Das AK, Rajkumar V, Verma AK, Swarup D. 2012. Moringa oleifera leaves Extract: A Natural Antioxidant for Retarding Lipid Peroxidation in Cooked Goat Meat Patties. J Food Sci Tech. 47: 585-91.

de La Salles AYF, Batista LF, de Souza BB, da Silva AF, de Barros Correia EL. 2017. Growth and reproduction hormones of ruminants subjected to heat stress. J Anim Behav Biometeorol. 5: 7-12.

de los Reyes M, Palomino J, Martínez V, Aretio C, Gutiérrez M. 2011. Acrosin release and 
acrosin activity during incubation in capacitating media using fresh and frozenthawed dog sperm. Biol Res. 44:139-44.

Durairajanayagam D, Agarwal A, Ong C, Prashast P. 2014. Lycopene and male infertility. Asian J Androl. 16: 420-5.

El-Tantawy WH. 2015. Antioxidant effects of Spirulina supplement against lead acetateinduced hepatic injury in rats. $\mathrm{J}$ Tradit Complement Med. 6: 327-31.

Ermiza E. 2012. Pengaruh paparan suhu terhadap kualitas spermatozoa mencit jantan (Mus musculus) Strain Jepang. Sainstis 1: 19-28.

Estrada E, Rodríguez-Gil JE, Rivera Del Álamo MM, Peña A, Yeste M. 2017. Effects of reduced glutathione on acrosin activity in frozen-thawed boar spermatozoa. Reprod Fertil Dev. 29: 283-93.

Handayani E, Supriatna I, Tumbelaka LI, Kaiin EM. 2021. Analisis Komparatif Kualitas Semen Beku yang Telah dan Belum Bersertifikasi Standar Nasional Indonesia. J Vet. 22: 207-15.

Lamando D, Soegianto A, Abadi A, Keman S. 2014. Antioxidant effects of sarang semut (Myrmecodia pendans) on the apoptosis of spermatogenic cels of rats exposed to plumbum. J Pharm Biol Chem Sci. 5: 28294.

Margaritelis NV, Cobley JN, Paschalis V, Veskoukis AS, Theodorou AA, Kyparos A, Nikolaidis MG. 2016. Going retro: Oxidative stress biomarkers in modern redox biology. Free Radic Biol Med. 98: 212.

Novita M, Sulaiman MI, Yura S. 2016. Pengaruh Jenis Pelarut Aktivitas Antioksidan dan Kandungan Fenol Beberapa Jenis Bayam dan Sayuran Lain. J Ilmiah Mahasiswa Pertanian Unsyiah 1: 935-40.

Ogunsola OA, Owalabi JO, Fabiyi OS, Nwobi NL, Faluyi B, Akinbola AS. 2017. Moringa Plant Consumption had Effects on Reproduction Functions in Male and Female Rat Models. J Dent Med Sci. 16: 82-6.

Panggalih A, Susilowati S, Maslachah L, Ratnani H, Suprayogi TW. 2021. The effect of watermelon (Citrullus lanatus) rind ethanolic extract on the number of Leydig, Sertoli, and spermatogenic cells of rat (Rattus novergicus) exposed to heat. Ovozoa 10: 7-11.

Pizzino G, Irrera N, Cucinotta M, Pallio G, Mannino F, Arcoraci V, Squadrito F, Altavilla D, Bitto A. 2017. Oxidative Stress: Harms and Benefits for Human Health. Oxid Med Cell Longev. 2017:8416763.

Prastyaningtyas K, Kurnijasanti R, Sugihartuti R, Susilowati S, Suprayogi TW, Eliyani H. 2021. The effect of red dragon fruit (Hylocereus polyrhizus) peel extract on Leydig cells number, seminiferous tubules diameter, and testicular weight of mice (Mus musculus) exposed to heat. Ovozoa 10: 1824.

Pratama R. 2019. Efek rumah kaca terhadap bumi. Buletin Utama Teknik 14: 120-26.

Pratiwi IN, Aligita W, Kaniawati M. 2021. Kajian potensi antioksidan dari tanaman herbal dan pengaruhnya terhadap penyakit Parkinson. J Ilmiah Farmasi 17: 80-95.

Raharjo R, Sudjarwo SA, I'tishom R. 2017. Effects of Red Dragon Fruit (Hylocereus polyrhizus) skin extract on lead acetate toxicity in the morphology of Balb/c MICE (Mus musculus) spermatozoa. Folia Medica Indonesiana 53: 237-41.

Riesco MF, Alvarez M, Anel-Lopez L, NeilaMontero M, Palacin-Martinez C, MontesGarrido R, Boixo JC, de Paz P, Anel L. 2021. Multiparametric Study of Antioxidant Effect on Ram Sperm Cryopreservationfrom Field Trials to Research Bench. Animals 11: 283.

Rohmah L, Triana IN, Sunarso A, Susilowati S, Hidajati N, Kurnijasanti R. 2018. Pengaruh pemberian ekstrak kulit semangka (Citrullus lanatus) terhadap motilitas dan viabilitas spermatozoa tikus (Rattus norvegicus) dengan paparan suhu panas. Ovozoa 7: 1316.

Sabés-Alsina M, Tallo-Parra O, Mogas MT, Morrell JM, Lopez-Bejar M. 2016. Heat stress has an effect on motility and metabolic activity of rabbit spermatozoa. Anim Reprod Sci. 173:18-23.

Sarfraz A, Qureshi AA, Shahid RU, Hussain M, Usman M, Umar Z. 2019. Maintenance of Thermal Homeostasis with Special 
Emphasis on Testicular Thermoregulation." Acta Vet Eurasia 45: 63.

Silva LKX, Sousa JS, Silva AOA, Lourenço Junior JB, Faturi C, Martorano LG, Franco IM, Pantoja MHA, Barros DV, Garcia AR. 2018. Testicular thermoregulation, scrotal surface temperature patterns and semen quality of water buffalo bulls reared in a tropical climate. Andrologia 50: 11-8.

Solihati N, Purwantara B, Supriatna I, Winarto A. 2013. Perkembangan sel-sel spermatogenik dan kualitas sperma pascapemberian ekstrak pegagan (Centella asiatica). Indones J Anim Vet Sci. 18: 192-201.

Subianto A, Boer R, Aldrian E, Perdinan P dan Kinseng R. 2018. Isu Perubahan Iklim dalam konteks Keamanan Nasional. J Ketahanan Nas. 24: 287-305.

Tavalaee M, Sadeghi N, Nasr-Esfahani MH. 2018. Effect of heat stress on Spermatogenesis. J Shahrekord Univ Med Sci. 20: 110-27.
Utami W, Mardawati E, Putri SH. 2020. Pengujian aktivitas antioksidan kulit Buah Naga Merah (Hylocereus polyrhizus) sebagai masker gel peel off. J Industri Pertanian 2: 95-102.

Vadnais ML, Cao W, Aghajanian HK, HaigLadewig L, Lin AM, Al-Alao O, Gerton GL. 2014. Adenine nucleotide metabolism and a role for AMP in modulating flagellar waveforms in mouse sperm. Biol Reprod. 90: 128.

Wagner H, Cheng JW, Ko EY. 2017. Role of reactive oxygen species in male infertility: An updated review of literature. Arab J Urol. 16: $35-43$.

Widiantoro K, Madyawati SP, Sardjito T, Hernawati T, Triana IN, Warsito SH. 2021. Kualitas post-thawing semen domba Merino dalam bahan pengencer berbasis susu skimkuning telur yang ditambah isolat crude protein Tirosine Kinase. Ovozoa 10: 39-45 